\title{
PEMEROLEHAN BAHASA PERTAMA PADA ANAK USIA 4 TAHUN DALAM TAHAPAN PENGEMBANGAN SINTAKSIS
}

\section{ACQUISITION OF FIRST LANGUANGE IN CHILDREN AGED 4 YEARS IN THE SYNTACTIC DEVELOPMENT STAGE}

\author{
Dantia Ayu Ningtiyas \\ Pendidikan Bahasa dan Sastra Indonesia \\ UIN Syarif Hidayatullah Jakarta \\ Pos-el: Dantiatiyas@gmail.com
}

\begin{abstract}
Abstrak
Penelitian ini bertujuan untuk memaparkan pemerolehan bahasa pertama pada anak melalui apa yang ia simak. Tujuan dari penelitian ini yaitu menjelaskan bagaimana pemerolehan bahasa pertama dan bagaimana anak usia empat tahun sudah dalam tahap pengembangan sintaksis. Dalam penelitian ini menggunakan survei dengan metode penelitian deskriptif kualitatif, yaitu menggambarkan dan mendeskripsikan pemerolehan bahasa pertama melalui pengembangan sintaksis pada usia empat tahun. Data yang diperoleh dalam penelitian ini merupakan hasil dari observasi lapangan dan wawancara dengan seorang anak laki-laki yang bernama Rizki Ramadhani yang tinggal di Klaten, Jawa Tengah. Usianya sudah menginjak empat tahun yang berarti Rizki dalam tahapan banyak kata dan dalam tataran kebahasaan Rizki dalam tahap pemerolehan sintaksis. Hasil dalam penelitian ini dapat disimpulkan bahwa pada Rizki, anak usia empat tahun mampu membuat kalimat-kalimat sederhana, kalimat tanya, dan kalimat suruh. Manfaat dari penelitian ini adalah untuk melihat bagaimana proses perkembangan sintaksis pada anak usia 4 tahun serta mengetahui pentingnya peran orang tua serta lingkungan untuk pemerolehan bahasa pertama pada anak.
\end{abstract}

Kata kunci: pemerolehan bahasa, bahasa ibu, pengembangan sintaksis.

\begin{abstract}
This study aims to describe first language acquisition in children through what they have seen. The purpose of this study is to explain how first language acquisition is and how four year olds are already in the syntactic development stage. In this study, using a survey with a qualitative descriptive research method, namely describing and describing the acquisition of first language through syntactic development at the age of empat years. The data obtained in this study are the result of field observations and interviews with a boy named Rizki Ramadhani who lives in Klaten, Central Java. He is already emapt years old, which means that Rizki is in the multi-word stage and at the linguistic level Rizki is in the syntactic acquisition stage. The results of this study concluded that for Rizki, empat year olds were able to make simple sentences, interrogative sentences, and ordered sentences.
\end{abstract}

Keywords: acquisition of language, first language, acquisition of syntax. 


\section{PENDAHULUAN}

Bahasa merupakan ujaran untuk menyampaikan sesuatu. Sesuatu yang dimaksud oleh penutur dapat dipahami dan dimengerti oleh kawan tutur melalui bahasa yang diungkapkan. Fungsi bahasa yang paling utama sejak seseorang belajar bahasa adalah untuk komunikasi. (Mar'at, 2005: 19). Selain pengertian bahasa untuk menyampaikan sesuatu, bahasa merupakan suatu alat komunikasi untuk menyampaikan maksud dan tujuan dari penutur bahasa tersebut. Menurut Samsunuwiyati (2005: 31) dalam komunikasi, setiap kalimat yang diucapkan mempunyai fungsi yang khusus. Kadang kala fungsinya ialah memeberitahukan, menanyakan atau memperingati tentang suatu kejadian atau fakta.

Bahasa merupakan suatu sistem simbol lisan yang arbitrer yang digunakan oleh anggota dalam suatu masyarakat bahasa untuk berkomunisasi dan berinteraksi antar sesama, berlandaskan atas budaya yang mereka miliki (Dardjowidjojo, 2012: 16). Dari pemaparan tersebut dapat disimpulkan bahwa bahasa bersifat arbitrer atau manasuka, kemanasukaan muncul dari hasil kesepakatan yang berada di dalam suatu kelompok masyarakat.

Bahasa hakikatnya dapat dikatakan sebagai suatu alat komunikasi, tetapi tidak semua alat komunikasi dapat dikatakan sebagai bahasa. Hockett dalam Nuryani (2013: 2) memberikan enam belas ciri komunikasi dapat dikatakan sebagai bahasa. Apabila salah satu dari keenam belas unsur tersebut tidak terdapat dalam suatu alat komunikasi, maka alat komunikasi tersebut tidak dapat dikatakan sebagai bahasa. Contohnya ayam dapat berkomunikasi dengan ayam yang lainnya, ayam akan 'berkokok'. Komunikasi yang terjadi pada ayam dengan 'berkokok' bukanlah menggunakan bahasa melainkan hanya alat komunikasi saja. Dari keenam belas unsur tersebut, salah satunya yaitu pembelajaran bahasa dan bahasa dapat dipelajari. Dalam hal ini psikolinguistik suatu ilmu yang mengkaji pembelajaran bahasa dan bahasa dapat dipelajari. Pembelajaran bahasa yang maknanya bahasa dapat dipelajari terbagi menjadi dua pokok pembahasan. Pokok yang pertama, yaitu pembelajaran bahasa yang diperoleh pada manusia sejak ia bayi.

Pembelajaran bahasa pada bayi termasuk dalam pembelajaran informal. Keberlangsungan pembelajaran bahasa pada bayi terjadi secara tidak sadar. Bayi tidak akan sadar saat menerima pembelajaran bahasa. Selain bayi tidak sadar telah terjadi pembelajaran bahasa pada dirinya, pembelajaran bahasa informal juga bersifat kebetulan dan tidak direncanakan. Berbeda dengan pembelajaran bahasa secara informal yang terjadi dengan secara tidak sadar, sedangkan pembelajaran bahasa secara formal adanya kesadaran sedang terjadinya pembelajaran bahasa. Umumnya pembelajaran formal memiliki perencanaan dan penyususnan yang matang dan disengaja. Pembelajaran bahasa formal akan memfokuskan dengan struktur-stuktur dalam bahasa.

Terdapat empat pokok pembicaraan yang dipelajari di dalam psikolinguistik menurut Dardjowidjojo (2012: 9) yaitu komprehensi (mengerti makna dan maksud dari ujaran tersebut), produksi (mengujarkan sesuatu seperti diujarkan), landasan biologis dan neurologis (manusia dapat berbahasa), pemerolehan bahasa (bersifat individu, cara anak memperoleh bahasa meraka). Dalam penelitian ini, peneliti akan berfokus pada pembahasan tentang pemerolehan bahasa pertama atau bahasa ibu, dan bagaimana seorang anak memperoleh bahasa mereka atau bahasa pertamanya.

Pemerolehan bahasa pertama atau yang biasa disebut sebagai bahasa ibu (first language aquistion) berkaitan erat dengan 
semua aktivitas seseorang dalam menguasai dan memahami bahasa ibunya (tarigan, 2013: 4). Melalui bahasa pertama seorang anak akan belajar berkomunikasi dan belajar menjadi anggota masyarakat melalui komunikasi. Mulanya bayi dilahirkan belum memiliki keahlian berbicara, keahlian dalam berbicara akan didapatkan setelah pemerolehan bahasa pertama atau sering disebut sebagai bahasa ibu yang telah didapatkannya.

Bahasa ibu diperoleh melalui interaksi dengan keluarga dan lingkungan masyarakat sekitar. Hal tersebut yang membuat anak memperoleh bahasa pertamanya. Bahasa pertama pada anak akan diperoleh bila anak tersebut belum memperoleh bahasanya sama sekali. Kemudian kini anak tersebut memperoleh bahasanya, maka bahasa tersebut dikatakan sebagai bahasa pertama atau bahasa ibu. Pemerolehan bahasa pada anak akan berlangsung secara alamiah pada saat anak belajar bahasa ibu, anak tidak menyadari bahwa mereka sedang memperoleh bahasa pertamanya. Dalam memperoleh bahasa pertamanya anak tidak melihat dari bentuk bahasanya tetapi anak hanya melihat dari fungsi komunikasinya.

Bahasa merupakan salah satu sarana atau alat untuk mengeksperikan perasaan, pikiran, dan keinginan dalam berkomunikasi. Gleason dalam Nuryani menyatakan bahwa dalam psikolinguistk terdapat proses bagaimana seorang anak menggunakan bahasa sebagai sarana atau alat komunikasi, yaitu 1) proses mendengar, memahami, dan mengingat sesuatu yang telah didengar (comprehension); 2) seseorang yang menyatakan sesuatu yang dikatakan (production); dan 3) belajar memahami atau memproduksi bahasa pertamanya (acquastion). Dalam penelitian ini lebih difokuskan pada penelitian ini akan membahas pemerolehan bahasa (language acquastion). (Nuryani, 2013: 88).
Penelitian ini akan berfokus pada pemerolehan bahasa pertama, cara mereka mendapatkan bahasa pertama mereka dengan faktor yang mempengaruhi pemerolehan bahasa, salah satunya faktor sosial lingkungan. Peneliti akan memfokuskan pada pemerolehan bahasa pertama atau bahasa ibu melalui pemerolehan sintaksisnya yaitu kalimat sederhana, kalimat pertanyaan, dan kalimat suruh. Kalimat sederhana yaitu terderi dari satu klausa, kalusa merupakan satuan dari gramatikal yang memiliki fungsi sebagai subjek (S) dan predikatnyan $(\mathrm{P})$.

\section{LANDASAN TEORI}

Bahasa merupakan alat komunikasi yang berupa sistem lambang bunyi yang digunakan oleh suatu masyarakat untuk berkomunikasi dan berinteraksi dengan sesama. Istilah komunikasi menurut etimologi berasal dari bahasa latin, yaitu communis, yang berarti common, yang berarti menyebarkan atau memberitahukan informasi kepada pihak lain guna mendapatkan pengertian yang sama. (Wursanto, 2005:20) Dari pengertian tersebut dapat dikatakan bahwa komunikasi merupakan pengiriman atau penerimaan pesan yang dilakukan oleh dua orang bahkan lebih yang dapat membangun realitas mereka didalam kehidupan sehingga pesan yang dimaksud dapat dipahami.

Keberadaan bahasa sejalan dengan keberadaan manusia itu sendiri. (Sudawarti, 2017: 13) Dalam kebahasaan terdapat beberapa bidang studi, salah satunya yaitu psikolinguistik. Psikolinguistik merupakan kajian yang baru dalam studi kasu tentang kebahasaan. Psikolinguistik menurut Darjowidjojo (2012: 7) yaitu ilmu yang mempelajari tahapan-tahapan dari suatu proses mental yang telah dialami oleh manusia dalam proses berbahasa. 
Pemerolehan bahasa merupakan suatu kejadian atau keadaan di mana seorang anak memperoleh dan mempelajari bahasa pertamanya tanpa disadari. Selain itu pemerolehan bahasa bersifat alami yang artinya pembelajaran bahasa ini disebut secara informal, karena pemerolehan bahasa yang terjadi kebetulan dan tidak direncanakan. Pemerolehan atau akuisisi bahasa merupakan proses yang berlangsung di dalam otak anak ketika ia memperoleh bahasa pertamanya atau yang biasa disebut bahasa ibunya (Chaer, 2003: 167). Pemerolehan bahasa pada anak, tidak akan sadar bahwa ia sedang memperoleh bahasa pertamanya, tetapi anak itu hanya sadar bahwa dirinya sedang menggunakan bahasa untuk alat komunikasinya.

Pemerolehan bahasa pertama terdapat dua faktor yang mempengaruhi anak dalam memperoleh kemampuannya berbahasa, salah satunya, yaitu faktor sosial lingkungan. Faktor sosial lingkungan akan mempengaruhi bagaimana seorang anak memperoleh bahasanya, melalui faktor sosial lingkungannya akan mempengaruhi bahasa pertamanya. Keluarga menjadi salah satu pengaruh terbesah dalam pemerolehan bahasa pertamanya, anak akan meniru bahasa yang dituturkan oleh ibunya. Oleh sebab itu faktor sosial lingkungan berpengaruh dalam pemerolehan bahasa.

Ingram dalam Nuryani (2013: 91) mengungkapkan terdapat empat tahapan yang terjadi pada anak dalam pemerolehan bahasa yang terbagi menjadi empat tahapan, yaitu 1) tahap pralinguistik (0-12 bulan); 2) Tahap satu-kata (12-18 bulan; 3) tahap dua kata (1824 bulan); dan 4) tahap banyak kata (3-5 tahun). Tahapan keempat yaitu tahap banyak kata, pada usia 3-5 tahun kemampuan anak dalam berkomunikasi sudah layaknya seperti orang dewasa, mereka mulai mampu atau mahir membuat kalimat pertanyaan, kalimat negatif, kalimat majemuk, kalimat pernyataan, dan kalimat lainnya (Nuryani, 2013: 94).

Langkah setelah anak memperoleh bahasanya, anak akan mulai mengembangkan perolehan bahasa pertama yang telah ia dapatkan. Salah satunya perkembangan sintaksis. Istilah sintaksis secara langsung berasal dari bahasa Belanda, yaitu syntaxis. Dalam bahasa Inggris digunakan istilah syntax. Sintaksis adalah telaah mengenai prinsip-prinsip dan proses yang dipergunakan untuk membangun kalimat-kalimat dalam bahasa tertentu. (Chomsky, 1957: 11). Selanjutnya menurut Ramlan, sintaksis merupakan bagian cabang ilmu bahasa yang membicarakan seluk beluk wacana, kalimat, klausa, dan frase. (2005: 18) Selain itu, sintaksis adalah pengaturan dan hubungan antara kata dengan satuan-satuan yang lebih besar atau antara satuan yang lebih besar itu dalam bahasa terkecil dalam bidang ini adalah kata (Noortyani, 2017: 52).

Perkembangan sintaksis yang dialami oleh anak biasanya akan berkembang mulai dari satu dua kata, sampai membuat kalimat. Dalam sintaksis, terdapat empat jenis kalimat, yaitu 1) kalimat berita atau deklaratif, kalimat ini berisikan pemberitahuan; 2) kalimat tanya atau interogatif, kalimat ini berisikan tentang pertanyaan kepada orang lain; 3) kalimat perintah imperatif, kalimat yang berisikan tentang menyuruh orang lain untuk melakukan sesuatu yang kita hendaki, 4) kalimat seruan tau ekslamatif, kalimat ini berisikan seruan yang menunjukkan keheranan Selain itu dalam sintaksis terdapat kalimat sederhana dan kalimat luas. Kalimat sederhana yaitu kalimat yang terdiri dari satu klausa, sedangkan kalimat luas terdiri dari dua klausa atau lebih. Kausa di sini dijelaskan sebagai suatu gramatikal yang terdiri dari S P baik disertai O, Pel, Ket ataupun tidak (Ramlan, 2005: 79). 


\section{METODE PENELITIAN}

Penelitian ini akan berbentuk deskriptif atau narasi dari sebuah data yang telah dianalisis. Menurut Furchan penelitian deskriptif yaitu suatu metode penelitian yang ditujukan untuk menggambarkan fenomena yang ada. (Furchan, 2004: 54). Penelitian ini menggunakan metode penelitian yaitu deskriptif kualitatif. Penelitian deskriptif kualitatif bertujuan untuk mengungkapkan informasi dalam bentuk kualitatif dengan pendeskripsian yang teliti dan penuh nuansa untuk menggambarkan secara cermat sifat-sifat suatu hal, keadaan, fenomena, dan tidak terbatas pada pengumpulan data melainkan meliputi analisis interpretasi data. (Sutopo, 2002: 27) Dengan menggunakan data yang berupa kata dan memaparkan hasil analisis dengan menggunakan narasi, maka penelitian ini menggunakan metode deskriptif kualitatif. Data yang digunakan berupa transkrip percakapan yang diambil pada bulan Desember 2019. Informan dalam penelitian ini, yaitu anak laki-laki yang berusia 4 tahun yang tinggal di Klaten, Jawa Tengah. Objek penelitian yaitu pemerolehan bahasa pertama yaitu bahasa ibu dalam tahapan tatanan kebahasaan pemerolehan sintaksis anak pada usia 4 tahun. Hal tersebut mencakup kalimat sederhana, dan kalimat pertanyaan, dan kalimat suruh.

Tehnik dalam pengumpulan data penelitian ini yaitu dengan observasi. Tehnik observasi dengan mengumpulkan data, dengan cara mengamati sumber data. Data diperoleh berbentuk video lalu ditranskrip, selain itu dalam penelitian ini menggunakan tehnik perekaman dan mencatat datadata yang diperlukan.

\section{Informan}

Informan dalam penelitian ini yaitu seorang anak laki-laki yang bernama Rizki Ramadhani berusia 4 tahun yang lahi di
Klaten, pada tanggal 11 Juli 2016 dia adalah anak kedua dari pasangan Bapak Kuswanto dan Ibu Mulyani. Sehari-hari Rizki tinggal bersama keluarganya, Rizki juga sering membantu ibu dan bapaknya berdagang di pasar. Rizki dikenal sangat aktif dalam berbicara, bahasa yang digunakan Rizki yaitu bahasa pertama atau biasa disebut bahasa ibu yang diperoleh Rizki yaitu bahasa Jawa, kesehariannya Rizki dalam berkomunikasi menggunakan bahas pertamanya yaitu bahasa Jawa.

\section{HASIL DAN PEMBAHASAN}

Melalui hasil obeservasi pada sumber data pemerolehan bahasa pertama dengan perkembangan sintaksis pada Rizki Ramadhani yang berusia 4 tahun dapat mencakup, yaitu kalimat sederhana, kalimat pertanyaa, dan kalimat suruh yang akan dipaparkan sebagai berikut.

\section{Data 1}

Rizki: fotenen pak karo kucing

$\frac{\text { Fotoin pak sama kucing }}{\mathrm{P}} \frac{\mathrm{S}}{\mathrm{Ket}}$

Bapak: iyo, lah koe senyum noh

Iya, lah kamu senyum dong

Data di atas diambil ketika Rizki yang sedang meminta bapaknya untuk mengambil foto Rizki. Selain itu Rizki. Dari data di atas kita dapat melihat kemampuan dalam berkomunikasi. Rizki sudah dapat menangkap tujuan dan konteks dari komunikasi tersebut. Dari data di atas Rizki mampu membuat kalimat sederhana yang memiliki klausa yang lengkap, kalimat tersebut memiliki fungsi sebagai subjek (S) dan predikatnyan (P). kalimat tersebut merupakan kalimat suruh, di mana Rizki meminta kepada bapaknya untuk memotret dirinya.

\section{Data 2}

Rizki: $B u$, aku arep papung

$\underline{\mathrm{Bu}}, \underline{\text { aku mau mandi }}$ 
S P

Ibu: $\quad$ kosek, ibu agek mangan

Sebentar ibu lagi makan

Data di atas diambil ketika Rizki baru pulang main dan ingin mandi. Dari data di atas Rizki mampu membuat kalimat sederhana. Pada kalimat tersebut terdapat (S) dan (P) dalam satu kalimat. Selain itu kalimat di atas memiliki kluasa yang lengkap. Hal tersebut termasuk dalam kalimat sederhana. Dari data di atas Rizki juga mampum membuat kalimat berita, di mana Rizki ingin memberi tahu kepada ibunya bahwa ia ingin mandi.

\section{Data 3}

Rizki: tukoke aku dholanan bu

Belikan aku mainin bu

$\mathrm{P} \quad \mathrm{O} \mathrm{O}$

Ibu: iyo sesok

Iya besok

Data di atas diambil ketika Rizki sedang melihat iklan mainan di tv, Rizki menyuruh ibunya untuk membelikan mainan tersebut. Pada kalimat yang dibentuk oleh Rizki memiliki kluasa yang lengkap, kemudia kalimat tersebut juga memiliki fungsi sebagai subjek (S) dan perdikat $(\mathrm{P})$. Hal tersebut termasuk dalam kalimat sederhana. Rizki sudah mampu membuat kalimat suruh, di mana Rizki meminta ibunya untuk membelikan mainan untuknya.

\section{Data 4}

Rizki: puss, mangan sing okeh yo

puss makan yang banyak ya

$\mathrm{S} \mathrm{P}$ ket

Mbah: lah koe mangan sing okeh noh, mosok kucing tok

Lah kamu juga makan yang banyak dong, masa kucing aja

Data di atas diambil ketika Rizki sedang memberi makan kucing-kucing peliharaan- nya. Dalam kalimat tersebut Rizki menyuruh untuk kucing tersebut makan yang banyak, Rizki berkomunikasi seakan-akan kucing tersebut memahami apa yang dia maksud. Hal tersebut membuktikan Rizki dapat memahami konteks kalimatnya tersebut. Selain itu dalam kalimat yang dikatakan Rizki terdapat fungsi subjek (S) dan predikat $(\mathrm{P})$, maka dari itu kalimat yang dibentuk Rizki merupakan kalimat sederhana yang berklausa lengkap. Kemudia kalimat tersebut merupakan kalimat suruh, di mana Rizki menyuruh kucing miliknya untuk makan yang banyak.

\section{Data 5}

Bapak: Rizki, muleh yo wis peteng iki loh Rizki, pulang ini udah gelap loh

Rizki: aku arep tuku es sek $\underline{\mathrm{Aku}} \underline{\mathrm{mau}}$ beli es dulu $\mathrm{S} \quad \mathrm{P}$

Bapak: yo, cepet

Yaudah, cepet

Data di atas diambil ketika Rizki yang disuruh untuk pulang kerumah karena hari mulai malam, kemudian Rizki izin kepada bapaknya untuk membeli es terlebih dahulu sebelum pulang. Pada kalimat di atas Rizki mampu membuat kalimat sederhana yang memiliki klausa lengkap, kalimat tersebut memiliki fungsi sebagai subjek (S) dan predikat $(\mathrm{P})$. kalimat tersebut masuk ke dalam kalimat berita, yang mana Rizki ingin memberi tahu bapaknya bahwa ia ingin membeli es terlebih dahulu sebelum pulan.

\section{Data 5}

Rizki: "kak Usup lagi moto aku, wes?" Kak Usup lagi foto aku, udah?

$\mathrm{S} \quad \mathrm{P} \mathrm{O}$

Kakak: hurong

Belum

Data di atas diambil ketika kaka Rizki yaitu Usup sedang mengambil foto untuk 
Rizki. Data tersebut diambil ketika Rizki memberi tahu orang yang berada bersamanya yang sedang dilakukan kakanya. Dari data di atas Rizki mampu membuat kalimat sederhana yang memiliki klausa yang lengkap, kalimat tersebut memiliki fungsi sebagai subjek (S) dan predikatnyan (P). kalimat tersebut merupakan kalimat tanya. Pada kalimat pertama, pertanyaan tersebut hanya dapat dijawab dengan 'sudah' atau 'belum'.

\section{Data 6}

Pembeli: lomboke piro?

Cabenya berapa?

Rizki: lomboke piro yo?, tigangewu Cabenya berapa ya? Tiga ribu S

Pembeli: tigangewu?, kok murahmen

Tiga ribu? Kok murah banget

Rizki: iyo

iya

Data di atas diambil ketika Rizki sedang di pasar untuk membantu ibunya yang berdagang. Rizki mampu menjawab pertanyaan yang diajukan oleh pembeli dengan baik, ia mampu menangkap tujuan komunikasi tersebut. Dari data di atas Rizki mampu membuat kalimat, kalimat tidak memiliki klausa yaitu tidak terdapat salah satu fungsi Subjek (S) dan Predikat (P). pada kalimat pertama Rizki mengajukan pertanyaan untuk meyakinkan dirinya berapa harga cabe tersebut, kemudian ia menjawabnya dengan yakin.

Pemaparan data di atas dapat dikatakan perkembangan sintaksis yang dimiliki oleh Rizki sangat baik. Rizki yang pada data satu dan data dua Rizki sudah mampu menggabungkan dua kata atau lebih. Selain itu kalimat yang diucapkan Rizki sudah dapat membuat pola kalimat lengkap yang strukturnya sederhana, pada anak seusia Rizki perkembangan sintaksis yang dimilikinya sangat baik. Perkembangan kalimat yang dimiliki oleh Rizki karena peniruan. Peniruan kepada bahasa pertama atau bahasa ibu lah yang mempengaruhi perkembangan sintaksis pada Rizki.

Bahasa pertama yang diperoleh Rizki yaitu bahasa Jawa. Karena latar belakang keluarga Bapak dan Ibu Rizki berasal dari Klaten Jawa. Rizki juga tinggal di Klaten, Jawa Tengah, hal tersebut yang mempengaruhi bahasa pertama yang Rizki peroleh merupakan bahasa Jawa. Hal tersebut termasuk dalam faktor lingkungan sosial. Pada anak usia 4-6 tahun perkembangan bahasa pada anak berkembang sangat pesat, selain itu pemakaian bahasa dalam berkomunikasi lebih produktif, dan dalam bertutur tata bahasa sudah mulai lebih teratur. Begitupun tuturan Rizki, Rizki sudah memiliki kemampuan dalam berkomunikasi, ia mampu membuat kalimat sederhana, kalimat pertanyaan, dan kalimat suruh. Semakin banyak Rizki berkomunikasi itu ankan mempengaruhi pada perkembangan bahasanya.

\section{PENUTUP}

Pemaparan penelitian yang telah dilakukan, dapat disimpulkan bahwa pemerolehan bahasa pertama atau bahasa ibu termasuk dalam pembelajaran bahasa yang informal. Secara tidak sadar Rizki telah memperoleh bahasa pertamanya, Rizki menggunakan bahasa sebagai alat komunikasi bukan sebagai pembelajaran.

Bahasa pertama yang dimiliki oleh Rizki yaitu bahasa Jawa. Hal tersebut dipengaruhi oleh dua faktor yaitu faktor biologis dan faktor lingkungan. Rizki merupakan anak kelahiran Jawa yang lingkungan sekitarnya menggunakan bahasa Jawa. Selain itu, tahapan pada pemerolehan bahasa yang sedang dialami oleh Rizki yaitu tahap banyak kata dan sudah memahami apa yang telah dituturkannya. Rizki sudah mampu 
membuat satu kalusa yang utuh yaitu terdapat subjek (S) dan predikat (P) dan telah memahami fungsi dari kalimat yang telah ia tuturkan. Selain itu Rizki telah mampu membuat dan membentuk kalimatkalimat seperti kalimat sederhana, kalimat pertanyaan, dan kalimat suruh.

\section{DAFTAR PUSTAKA}

Dardjowidjojo, Soenjono. 2003. Psikolinguistik: Pengantar Pemahaman Bahasa Manusia, Jakarta: Yayasan Pustaka Obor.

Nuryani dan Dona Aji Karunia. 2013. Psikolinguistik, Tangerang Selatan: Mazhab Ciputat).

Tarigan, Henry Guntur. 2011. Pengajaran Analisis Kesalahan Berbahasa, Bandung: Angkasa.

Dardjowidjojo, Soenjono. 2012. Psikolinguistik: Pengantar Pemahaman Bahasa Manusia ed.2, Jakarta: Yayasan Pustaka Obor Indonesia.

Chaer, Abdul. 2003. Psikolinguistik Kajian Teoretik (Jakarta: Rineka Cipta.

Wursanto. 2005. Dasar-Dasar Ilmu Komunikasi. Yogyakarta : CV. Andi Offset.

Sutopo, H.B. 2002. “Metodelogi Penelitian Kualitatif Dasar Teori dan Terapannya dalam Penelitian". Surakarta: Sebelas Maret University Press.

Suryana. 2010. Metodologi Penelitian Model Praktis Penelitian Kuantitatif dan kualitatif. Depok: Universitas Indonesia.

Noortyani, Rusma. 2017. Buku Ajar Sintaksi. Yogyakarta: Penebar Pustaka Media.

Mar'at, Samsunuwiyati. 2005. Psikolinguistik: Suatu Pengantar. Bandung: PT. Refika Aditama.

Tarigan, Henry Guntur. 2009. Psikolingustik. Bandung, Angkasa. 